\title{
FAKTOR DOMINAN YANG MEMENGARUHI KEPUTUSAN NASABAH UNTUK MENABUNG DI BANK SYARIAH, BPRS, DAN KSPPS
}

\section{THE DOMINANT FACTOR AFFECTING COSTUMER DECISION TO SAVE MONEY IN THE ISLAMIC BANK, ISLAMIC RURAL BANK (BPRS), AND KSPPS (ISLAMIC COOPERATIVES)}

\author{
Ranti Wiliasih'1a; Fathia Shadrina² \\ 1aProgram Studi Ekonomi Islam Fakultas Ekonomi dan Manajemen Institut Pertanian \\ Bogor, 16680 \\ ${ }^{2}$ Program Studi Ekonomi Islam Fakultas Ekonomi dan Manajemen Institut Pertanian \\ Bogor, 16680
}

(Diterima oleh Dewan Redaksi 01-11-2017)

(Dipublikasikan oleh Dewan Redaksi 18-12-2017)

\begin{abstract}
This research aims to study the dominant factor affecting costumer decision to save money in the Islamic bank, Islamic rural bank (BPRS), and Islamic cooperative (KSPPS). The research was carried out from March until May 2017 in Bank Syariah Mandiri branch Dramaga, BPRS Amanah Ummah, and KSPPS Tadbiirul Ummah. The research used factor analysis method. The result showed the dominant factor affecting the costumer decision for saving on Islamic banking is service, on BPRS is sharia compliance, and on KSPPS is credibility of the institution.
\end{abstract}

Keywords: Factor Analysis, Islamic Bank, BPRS, KSPPS, and Saving

\begin{abstract}
ABSTRAK
Tujuan penelitian ini adalah mengetahui faktor dominan yang memengaruhi keputusan nasabah untuk menabung pada Bank Syariah, BPRS, maupun KSPPS. Penelitian ini dilakukan sejak bulan Maret hingga Mei 2017 di Bank Syariah Mandiri KCP Dramaga, BPRS Amanah Ummah, dan KSPPS Tadbiirul Ummah. Metode yang digunakan adalah analisis faktor. Hasil analisis data menunjukkan bahwa faktor dominan yang memengaruhi keputusan nasabah untuk menabung pada Bank Syariah adalah faktor pelayanan, adapun pada BPRS adalah faktor kesesuaian dengan prinsip syariah, dan pada KSPPS berupa faktor kredibilitas lembaga.
\end{abstract}

Kata kunci: Analisis Faktor, Bank Syariah, BPRS, KSPPS, dan Tabungan

Ranti Wiliasih. 2017. Faktor Dominan yang Memengaruhi Keputusan Nasabah untuk Menabung di Bank Syariah, Bank Perkreditan Rakyat Syariah (BPRS) dan Koperasi Simpan Pinjam dan Pembiayaan Syariah (KSPPS). Jurnal Nisbah 3 (2): 442 - 461 


\section{PENDAHULUAN}

Indonesia menganut dual banking system yaitu penggunaan sistem keuangan syariah dan sistem keuangan konvensional secara bersamaan. Perbankan merupakan salah satu bagian dari lembaga keuangan syariah yang sudah berkembang dibandingkan dengan lembaga keuangan lainnya dalam sistem keuangan syariah. Pada industri perbankan syariah terdapat Bank Syariah dan juga Bank Pembiayan Rakyat Syariah yang dikenal dengan BPRS.

Selain perbankan syariah dan BPRS, lembaga non formal seperti KSPPS mengalami peningkatan yang signifikan. KSPPS pada awalnya dikenal dengan nama Baitul Mal wa Tamwil (BMT) dengan badan hukum dibawah Kementerian Koperasi dan UKM. BMT mengalami perubahan nama menjadi Koperasi Usaha Simpan Pinjam dan Pembiayaan Syariah (KSPPS) berdasarkan Peraturan Kementerian Koperasi dan Usaha Kecil dan Menengah No. 16/ PER/ M.KUKM/ IX/ 2015. Kementerian Koperasi dan UKM dalam republika.co.id pada tahun 2015 menyatakan Koperasi Jasa Keuangan Syariah (KJKS) dalam bentuk BMT telah mencapai aset sebesar Rp 4.7 triliun dan jumlah pembiayaan sebesar $\mathrm{Rp} 3.6$ triliun. Secara umum setiap lembaga keuangan syariah memiliki fungsi yang sama, yaitu berfungsi sebagai lembaga penghimpun dana dan juga penarik dana dari masyarakat. Salah satu cara menghimpun dana dari nasabah lembaga keuangan syariah adalah menggunakan produk tabungan syariah.

Pertumbuhan lembaga keuangan syariah yang pesat membuat persaingan untuk memperoleh nasabah menjadi ketat. Lembaga keuangan syariah harus memiliki keunggulan masing-masing agar tetap memperoleh nasabah dan kinerja keuangan yang tetap stabil.
Masing-masing lembaga memiliki karakteristik, kekurangan, dan kelebihan yang berbeda.

Bank Syariah memiliki keunggulan dibandingkan dengan lembaga keuangan syariah yang lain, yaitu termasuk salah satu lembaga keuangan syariah yang dijamin oleh Lembaga Penjamin Simpanan (LPS), sehingga menyimpan uang di Bank Syariah lebih aman dan terjamin, memiliki mesin Anjungan Tunai Mandiri (ATM) yang lokasinya tersebar di setiap wilayah. Hal ini memudahkan nasabah untuk beberapa jenis transaksi, sehingga nasabah tidak harus selalu mengunjungi kantor cabang atau kantor pusat Bank Syariah.

BPRS juga dijamin oleh LPS, namun pada umumnya kinerja BPRS fokus pada UMKM dan belum memiliki fasilitas ATM. KSPPS umumnya melayani kalangan menengah ke bawah berdasarkan prinsip syariah. Jasa yang disediakan KSPPS membantu masyarakat untuk membantu aktivitas pertumbuhan dan perkembangan ekonomi masyarakat. KSPPS memiliki sistem jemput bola, yaitu petugas KSPPS mendatangi nasabah untuk bertransaksi keuangan yang biasanya dilakukan pada kurun waktu harian, mingguan, bulanan, maupun tahunan. Selain tabungan dan pembiayaan, KSPPS juga memberi fasilitas pengumpulan dana zakat, infak, sedekah, dan wakaf untuk disalurkan kepada mustahiq (orang yang berhak menerima dana zakat). Letak KSPPS yang berada di tengah-tengah atau dekat pasar merupakan bentuk upaya KSPPS agar dekat dengan konsumen sehingga memudahkan konsumen bertransaksi (Rokhman 2016).

Bogor merupakan salah satu daerah dimana ketiga jenis lembaga ini tumbuh dan berkembang. Sebagai daerah dengan mayoritas penduduk yang beragama Islam, perkembangan ketiga lembaga keuangan Islam ini 
cukup baik. Adapun tiga lembaga keuangan yang lokasinya tidak terlalu jauh diantaranya Bank Syariah Mandiri KCP Dramaga, BPRS Amanah Ummah, dan KSPPS Tadbiirul Ummah.

Persaingan yang ketat antara lembaga keuangan dan juga lembaga keuangan syariah memerlukan strategi khusus bagi masing-masing lembaga untuk dapat meningkatkan transaksi usahanya termasuk tabungan. Untuk meningkatkan jumlah tabungan setiap tahunnya, lembaga keuangan syariah harus bisa meningkatkan jumlah nasabah dan mempertahankan nasabah. Oleh karena itu, diperlukan pengetahuan mengenai sejumlah faktor yang memengaruhi ketertarikan masyarakat untuk menabung di setiap jenis lembaga keuangan syariah, sehingga diharapkan dapat meningkatkan pelayanan masingmasing lembaga terhadap masyarakat.

\section{Faktor-Fakor Yang Memengaruhi Keputusan Nasabah Untuk Menabung Berdasarkan Penelitian Sebelumnya Promosi}

Promosi merupakan salah satu faktor penentu keberhasilan suatu program pemasaran. Seberapa bagusnya suatu produk, bila konsumen belum pernah mendengarnya dan tidak yakin bahwa produk tersebut akan berguna bagi konsumen, maka konsumen tidak akan membelinya. Tujuan utama dari promosi adalah menginformasikan, memengaruhi dan membujuk, serta mengingatkan pelanggan sasaran tentang perusahaan dan bauran pemasarannya.

Secara umum bentuk-bentuk promosi memiliki fungsi yang sama, tetapi bentuk-bentuk tersebut dapat dibedakan berdasarkan tugas-tugas khususnya. Beberapa tugas khusus itu disebut dengan bauran promosi (promotion mix) yang mencakup personal selling, mass selling, promosi penjualan, public relation, dan direct marketing.

Penelitian Rokman dan Zamroni (2016) menyatakan bahwa korelasi yang terjadi antara promosi dengan keputusan memilih Bank Syariah memiliki hubungan yang berbanding lurus, signifikan, dan searah, yang artinya semakin besar nilai promosi, maka semakin tinggi nilai keputusan memilih Bank Syariah.

Berdasarkan penelitian yang dilakukan oleh Musnaini (2010) salah satu faktor yang memengaruhi nasabah non muslim menentukan keputusan memilih produk Bank Syariah di Kota Jambi adalah faktor promosi. Hasil penelitian ini menunjukkan promosi berpengaruh positif signifikan terhadap keputusan nasabah non muslim menggunakan produk Bank Syariah. Semakin baik promosi yang dilakukan oleh Bank Syariah, semakin banyak nasabah yang memutuskan untuk menggunakan produk Bank Syariah.

\section{Pelayanan}

Suatu layanan (service) berasal dari orang atau individu, bukan dari suatu perusahaan. Suatu pelayanan akan terbentuk karena adanya proses pemberian layanan tertentu dari pihak penyedia layanan kepada pihak yang dilayani. Layanan dapat diberikan antara seseorang dengan seseorang, seseorang dengan kelompok, kelompok dengan seseorang, atau orang-orang dalam organisasi. Suatu layanan dapat diberikan secara sukarela seperti gotong royong dan komersil. Layanan yang diberikan secara komersil terdiri dari pihak yang menyediakan layanan bagi pihak lain yang bersedia untuk membayar.

Penyedia layanan (service provider) adalah pihak yang dapat memberikan suatu layanan tertentu kepada konsumen, baik berupa layanan dalam bentuk penyediaan dan penyerahan barang (goods) atau jasa- 
jasa (services). Dalam praktiknya, para pelaku bisnis mengartikan penyedia pelayanan sebagai pihak yang mampu memberikan nilai tambah yang nyata kepada konsumen.

Penerima layanan (service receiver) adalah mereka yang disebut sebagai konsumen (consumer) atau pelanggan (costumer) yang menerima layanan dari para penyedia layanan. Dalam praktiknya, para pelaku bisnis mengartikan penerima layanan sebagai pihak yang menerima suatu nilai tambah nyata dari penyedia layanan.

Pada penelitian Rokhman (2016) menyatakan bahwa kualitas pelayanan memiliki hubungan yang signifikan dan positif terhadap kepuasan nasabah pembiayaan pada BMT di Kudus. Berbagai komponen dari kualitas pelayanan seperti kualitas sumber daya manusia, pelayanan yang cepat dan ramah, jaminan keamanan transaksi serta berbagai komponen penting dalam kualitas pelayanan dianggap cukup baik untuk mengukur kepuasan nasabah.

Berdasarkan hasil penelitian Yarsi (2013) faktor pelayanan merupakan faktor kedua terpenting yang dipertimbangkan oleh nasabah BPRS dalam menentukan penggunaan jasa BPRS. Nasabah BPRS sangat mementingkan keramahan, karyawan yang pendiam dan egois tidak diperlukan di BPRS. Hal ini dipahami karena segmen nasabah BPRS adalah kelompok masyarakat yang sangat menjunjung tinggi kekeluargaan dan kepedulian.

\section{Penelitian Daulay}

menyatakan bahwa pelayanan bernilai positif yang artinya pelayanan searah dengan keputusan menabung nasabah. Dengan kata lain pelayanan berpengaruh positif terhadap keputusan menabung nasabah Bank Syariah di Kota Medan. Dengan demikian apabila pelayanan semakin baik dan ditingkatkan maka jumlah nasabah yang menabung akan meningkat, sebaliknya apabila kualitas pelayanan berkurang maka nasabah yang menabung akan berkurang pula.

\section{Kredibilitas Lembaga}

Kredibilitas adalah hubungan saling memengaruhi antara kepercayaan, sikap konsumen, dan kegiatan pemasaran. Hubungan antara ketiga hal itu sangat penting bagi pemasar karena akan menentukan strategi pemasaran yang berhasil. Hubungan antara kepercayaan dan sikap terdapat dalam Teori keseimbangan Heider.

Teori Keseimbangan Heider menjelaskan bahwa manusia dianggap selalu menjaga keseimbangan antara kepercayaan yang ada pada dirinya dan evaluasi. Artinya orang akan mencari keseimbangan jika informasi baru yang diterimanya tidak sesuai dengan kepercayaan yang selama ini diyakininya. Dalam teori ini ada tiga elemen yang harus ada agar proses keseimbangan bisa tercapai. Tiga elemen tersebut, yaitu: orang yang merasakan, sikap terhadap suatu objek, dan objek lain yang berhubungan dengan objek pertama.

Pengaruh kepercayaan terhadap sikap dan pengaruh sikap terhadap perilaku secara umum bergantung pada keterlibatan konsumen dengan pembeliannya. Keterlibatan yang tinggi dari konsumen atas pembeliannya disebabkan oleh tingginya hubungan antara kepercayaan, sikap, dan perilaku. Penelitian Abdillah et al (2015) menyatakan bahwa kredibilitas lembaga pengelola zakat berpengaruh signifikan terhadap kepercayaan masyarakat pada lembaga pengelola zakat. Semakin tinggi kredibilitas masyarakat terhadap lembaga, semakin tinggi pula kepercayaan masyarakat untuk menyalurkan zakat melalui lembaga zakat. 


\section{Kesesuaian dengan Prinsip Syariah}

Dalam Islam, motif aktifitas ekonomi lebih diarahkan pada pemenuhan kebutuhan dasar (needs) yang tentu ada batasnya, meskipun bersifat dinamis sesuai tingkat ekonomi masyarakat pada saat itu. Selain itu, kepuasan dalam Islam tidak hanya terbatas pada benda-benda konkret (materi), tetapi juga tergantung pada seseuatu yang bersifat abstrak, seperti amal saleh yang dilakukan manusia. Jadi, perilaku ekonomi dalam Islam cenderung mendorong keinginan pelaku ekonomi sama dengan kebutuhannya, yang dapat direalisasikan dengan adanya nilai dan norma dalam akidah dan akhlak Islam.

Ekonomi Islam adalah ilmu yang mempelajari segala perilaku manusia dalam memenuhi kebutuhan hidupnya dengan tujuan memperoleh falah (kedamaian dan kesejahteraan duniaakhirat). Perilaku manusia disini berkaitan dengan landasan-landasan syariah sebagai rujukan berperilaku dan kecenderungan-kecenderungan dari fitrah manusia. Kedua hal tersebut berinteraksi dengan porsinya masingmasing sehingga terbentuk sebuah mekanisme ekonomi yang khas dengan dasar-dasar nilai ilahiah. Prinsip-prinsip ekonomi Islam yang sering disebut dalam berbagai literatur ekonomi Islam dapat dirangkum menjadi lima hal, yaitu:

1) Hidup hemat dan tidak bermewahmewahan

2) Menjalankan usaha-usaha yang halal

3) Mengimplementasikan zakat

4) Penghapusan atau pelarangan riba

5) Pelarangan maysir (judi/spekulasi)

Berdasarkan penjelasan di atas sistem ekonomi Islam berbeda dengan sistem ekonomi konvensional. Sesuai dengan pradigma ini, ekonomi Islam tidak lebih dari sebuah aktivitas ibadah dari rangkaian ibadah pada setiap jenis aktifitas hidup manusia. Jadi dapat disimpulkan bahwa ketika ada istilah ekonomi Islam, artinya adalah beraktivitas ekonomi menggunakan aturan dan prinsip Islam.

$$
\text { Penelitian Yarsi }
$$

menyatakan bahwa penerapan syariat Islam sebagai tingkat kepentingan utama (terpenting) baik bagi responden BPRS maupun bank umum/unit usaha syariah untuk memilih menjadi nasabah Bank Syariah. Demikian juga ketika diidentifikasi indikatornya, hasil penelitian ini menyatakan bahwa menjalankan hukum Islam adalah yang terpenting dalam penerapan syariat Islam itu sendiri.

\section{Lokasi Lembaga}

Lokasi berhubungan dengan keputusan yang dibuat oleh perusahaan mengenai di mana operasi dan stafnya akan ditempatkan, yang paling penting dari lokasi adalah tipe dan tempat interaksi yang terlibat. Terdapat tiga macam tipe interaksi antara penyedia jasa dan pelanggan yang berhubungan dengan pemilihan lokasi, yaitu sebagai berikut:

1) Pelanggan mendatangi penyedia jasa

2) Penyedia jasa mendatangi pelanggan

3) Penyedia jasa dan pelanggan melakukan interaksi melalui perantara

Untuk tipe interaksi dimana pelanggan mendatangi penyedia jasa, letak lokasi menjadi sangat penting. Didalam interaksi ini penyedia jasa yang menginginkan pertumbuhan dapat mempertimbangkan menawarkan jasa mereka di beberapa lokasi. Jika penyedia jasa mendatangi pelanggan, maka letak lokasi menjadi tidak begitu penting meskipun perlu dipertimbangkan pula kedekatan terhadapa pelanggan untuk menjaga kualitas jasa yang akan diterima. Sementara itu dalam kasus penyedia 
jasa dan pelanggan menggunakan media perantara dalam berinteraksi, maka letak lokasi dapat diabaikan meskipun beberapa media perantara memerlukan interaksi fisik antara mereka dengan pelanggan.

Berdasarkan hasil penelitian Rokhman dan Zamroni (2016) hubungan antara lokasi dengan keputusan nasabah memilih Bank Syariah adalah berbanding lurus, sehingga dapat disimpulkan bahwa hubungan lokasi dengan keputusan memilih bank umum syariah di Kota Kudus adalah sangat kuat, signifikan, dan searah.

\section{Lingkungan Tempat Tinggal Nasabah}

\begin{tabular}{lcr}
\multicolumn{2}{c}{ Lingkungan tempat } & \multicolumn{1}{c}{ tinggal } \\
nasabah disebut juga & dengan \\
segmentasi & geodemografis. & Jenis \\
segmentasi & ini didasarkan & pada
\end{tabular} pendapat bahwa orang yang hidup dengan satu sama lain mungkin mempunyai keuangan, selera, pilihan, gaya hidup, dan kebiasaan konsumsi yang sama.

Demografi adalah telaah mengenai populasi manusia dalam arti jumlah, kerapatan, lokasi, umur, jenis kelamin, ras, dan jenis pekerjaan. Lingkungan demografi sangat diperhatikan oleh pemasar karena melibatkan manusia dan manusialah yang membentuk pasar. Geodemografis merupakan sebuah kombinasi dari karakteristik demografis dan gaya hidup konsumen dalam cluster geografis. Perusahaan riset pemasaran telah mengembangkan sistem klasifikasi, atau clustering yang mengidentifikasi segmen-segmen geodemografis yang berbeda.

$$
\text { Kata geodemografis ialah }
$$
gabungan dari kata geografis dan demografi, yang mendeskripsikan targeting dalam bentuk ini. Dasar pemikiran yang menjadi landasan geodemographic targeting adalah bahwa orang-orang yang menetap di area yang sama, misalnya bertetangga atau dalam satu zona kode area, juga memiliki persamaan dalam demografi dan gaya hidup. Beberapa perusahaan mengembangkan layanan yang menghilangkan batas area geografis ke dalam common group, atau cluster, dimana terdapat orang-orang dengan karakteristik demografis serta gaya hidup yang sama.

Penelitian Handayani dan Hanik (2014) menyatakan bahwa faktor sosial berpengaruh signifikan terhadap keputusan memilih perbankan syariah. Faktor sosial merupakan faktor yang melihat perilaku komunikasi nasabah sehari-hari. Nasabah bisa berkomunikasi di lingkungan tempat tinggal, tempat kerja dan masih banyak lagi.

\section{MATERI DAN METODE}

Tabungan syariah adalah tabungan yang sesuai dengan Fatwa Dewan Syariah Nasional No. 02/DSNMUI/IV/2000. Tabungan syariah adalah simpanan berdasarkan akad mudharabah atau wadiah atau akad lain yang tidak bertentangan dengan prinsip syariah yang penarikannya dapat dilakukan menurut syarat dan ketentuan tertentu yang disepakati, tetapi tidak dapat ditarik dengan cek, bilyet giro, dan/atau alat lainnya yang dipersamakan dengan itu.

\section{Metode Penelitian}

Penelitian ini dibatasi pada nasabah yang menabung di Bank Syariah Mandiri, BPRS Amanah Ummah, dan KSPPS Tadbiirul Ummah Kabupaten Bogor. Penelitian ini menggunakan data primer. Metode pengumpulan data dalam penelitian ini berupa metode survei yang dilakukan dengan cara menyebar kuesioner dan wawancara. Sampel diambil dengan teknik nonprobability sampling. Nonprobability sampling adalah teknik pengambilan sampel yang tidak memberi 
peluang/kesempatan sama bagi setiap unsur atau anggota populasi untuk dipilih menjadi sampel. Metode pengumpulan data menggunakan metode purposive sampling, yaitu teknik pengambilan sampel sumber data dengan pertimbangan tertentu (Sugiyono 2010). Pertimbangan tersebut adalah nasabah nasabah Bank Syariah Mandiri KCP Dramaga, BPRS Amanah Ummah, dan KSPPS Tadbiirul Ummah di Kabupaten Bogor. Jumlah sampel dalam penelitian ini adalah 90 responden, yang terdiri dari 30 responden Bank Syariah Mandiri, 30 responden BPRS Amanah Ummah, dan 30 responden KSPPS Tadbiirul Ummah.

Data yang diperoleh dari hasil kuesioner diolah dan dianalisis. Pengolahan data menggunakan perangkat lunak Microsoft excel 2013 dan Statistical Package for Social Sciene (SPSS) 18.

\section{Skala Likert}

Skala likert digunakan untuk mengukur sikap, pendapat, dan persepsi seseorang atau sekelompok orang tentang fenomena sosial. Indikator pengukur skala ini berupa kata-kata, antara lain: Sangat Setuju (SS), Setuju (S), Ragu-ragu (R), Tidak Setuju (TS), dan Sangat Tidak Setuju (STS).

\section{Analisis Faktor}

Analisis faktor merupakan suatu teknik untuk mengelompokkan sejumlah variabel yang saling berkorelasi, menjadi beberapa kelompok (faktor) yang masing-masing menggambarkan suatu dimensi atau konsep tertentu. Hasil analisis faktor dapat digunakan pula untuk mengelompokkan objek berdasarkan ciri faktor yang terbentuk. Berikut adalah persamaan akhir dari metode analisis faktor.

$$
\begin{aligned}
& Z_{i}=a_{i 1} F_{1}+a_{i 2} F_{2}+\ldots+a_{i j} F_{j}+e_{i} \\
& \mathrm{Z}_{\mathrm{i}} \quad \text { : Variabel amatan ke-i yang telah } \\
& \text { distandarisasi } \\
& \mathrm{a}_{\mathrm{ij}} \quad \text { : Loading factor untuk variable } \\
& \text { amatan ke-i dan faktor ke-j } \\
& \text { (besarnya korelasi Pearson } \\
& \text { antara variabel amatan ke-i } \\
& \text { dengan faktor ke-j) } \\
& \mathrm{F}_{\mathrm{j}} \quad \text { : Faktor ke-j (communal factor ke } \\
& \text { j) } \\
& \text { e : error }
\end{aligned}
$$

\section{Uji Keiser Meyer Olkin Measure of Sampling Adequency (KMO-MSA)}

Alat analisis yang digunakan adalah Keiser Meyer Olkin (KMO) dan Bartlet's test. Pengujian ini bertujuan untuk menyaring variabel-variabel yang akan dianalisis lebih lanjut. Persyaratan pokok yang harus dipenuhi ialah angka MSA harus diatas 0.5 .

\section{Uji Principal Component Analysis (PCA)}

Setelah sejumlah variabel terpilih, maka dilakukan reduksi variabel hingga menjadi satu atau beberapa faktor dengan metode PCA. Hasilnya menampilkan tabel communalities dan tabel Total Variance Explained (TVE). Semakin besar nilai communalities $(>0.5)$, maka semakin baik analisis faktor karena semakin besar karakteristik variabel asal yang dapat diwakili oleh faktor yang terbentuk. Pada tabel TVE terdapat initial eigenvalues yang menunjukkan jumlah faktor yang terbentuk, selain itu, terdapat nilai percent of variance yang menunjukkan keragaman yang dapat digambarkan oleh faktor yang terbentuk.

Variabel yang sudah masuk ke dalam beberapa faktor, perlu dilakukan proses rotasi terhadap seluruh variabel. Metode yang digunakan dalam proses rotasi ini adalah metode varimax. Proses ini dapat memperjelas kedudukan variabel terhadap faktor yang terbentuk 
(loading factor) nilainya harus berada di atas 0.5 .

\section{Menamakan faktor}

Langkah terakhir adalah memberi nama pada faktor yang terbentuk dari hasil reduksi. Penamaan faktor bergantung pada nama-nama variabel yang menjadi satu kelompok dengan interpretasi masing-masing analisis dan aspek lainnya.

\section{Operasional Variabel}

Pada penelitian ini jumlah variabel yang dianalisis sebanyak 6 variabel yaitu promosi, pelayanan, kredibilitas lembaga, kesesuaian dengan prinsip syariah, lokasi lembaga, dan lingkungan tempat tinggal nasabah.

1. Promosi adalah bagaimana LKS mengiklankan produk dan lembaganya hingga sampai ke telinga nasabah.

2. Pelayanan adalah pendapat nasabah mengenai pelayanan yang diberikan oleh LKS.

3. Kredibilitas lembaga adalah kepercayaan nasabah terhadap LKS untuk menyimpan dan mengelola dananya.

4. Kesesuaian dengan prinsip syariah adalah kesesuaian lembaga dengan prinsip-prinsip umum ekonomi syariah.

5. Lingkungan tempat tinggal nasabah adalah seberapa berpengaruh tempat tinggal terhadap minat menabung nasabah di LKS.

6. Lokasi adalah tempat LKS berada.

\section{HASIL DAN PEMBAHASAN}

\section{Gambaran Umum Bank Syariah Mandiri}

Bank Syariah Mandiri adalah bank yang didirikan pada tanggal 25 Oktober 1999 di Jakarta dan mulai beroperasi pada tanggal 1 November 1999. Saat ini Bank Syariah Mandiri memiliki 773 kantor cabang yang tersebar di seluruh provinsi di Indonesia. Salah satu cabang
Bank Syariah Mandiri terdapat di Dramaga yang berada di Jalan Perwira No. 151 Dramaga, Bogor.

Salah satu jenis pelayanan yang disediakan oleh Bank Syariah Mandiri adalah layanan tabungan. Penarikan dan setoran tabungan dapat dilakukan setiap saat selama jam kerja di konter BSM atau melalui ATM.

Tabel 1. Perkembangan Tabungan, Deposito, Pembiayaan, dan Aset Bank Syariah Mandiri 2014-2016

\begin{tabular}{|l|c|c|c|c|}
\hline $\begin{array}{c}\text { Keteranga } \\
\mathrm{n} \\
\text { (Juta } \\
\text { Rupiah) }\end{array}$ & 2014 & 2015 & 2016 & $\begin{array}{c}\text { Perke } \\
\text { mban } \\
\text { g-an } \\
(\%)\end{array}$ \\
\hline Tabungan & 22161 & 24986 & 27751 & 9.96 \\
& 015 & 810 & 227 & \\
\hline Deposito & 31935 & 31239 & 35268 & 11.42 \\
& 906 & 699 & 859 & \\
\hline Pembiaya & 11507 & 14275 & 17397 & 17.94 \\
an & 671 & 077 & 053 & \\
\hline Aset & 66942 & 70799 & 78831 & 10.19 \\
& 422 & 017 & 722 & \\
\hline
\end{tabular}

Sumber: ojk.go.id (2017)

Total tabungan sampai akhir tahun 2016 adalah Rp27 triliun, jumlah tabungan ini selalu meningkat setiap tahunnya. Dana pihak ketiga berupa tabungan dan deposito meningkat secara rata-rata yaitu sebesar 9.96\% dan $11.42 \%$. Total pembiayaan dan aset Bank Syariah Mandiri terus meningkat setiap tahunnya dengan perkembangan sebesar $17.94 \%$ untuk pembiayaan dan sebesar $10.19 \%$ untuk aset.

\section{Gambaran Umum BPRS Amanah Ummah}

Bank Pembiayaan Rakyat Syariah Amanah Ummah adalah lembaga keuangan syariah yang diresmikan pada tanggal 8 Agustus 1992 di Bogor, Jawa Barat. BPRS Amanah Ummah terletak pada Jl Raya Leuwiliang No.1 di Kabupaten Bogor, Jawa Barat. BPRS Amanah Ummah berdiri di kawasan yang dekat dengan pasar, terminal, dan perumahan. Letak BPRS Amanah Ummah yang strategis ini membuat mempermudah akses nasabah menuju kantor BPRS Amanah Ummah. 
BPRS Amanah Ummah memiliki fasilitas Tabungan Wadiah Ummah. Tabungan ini merupakan tabungan yang menggunakan akad wadiah yad dhomanah, yaitu nasabah menitipkan uang kepada BPRS, dimana BPRS memiliki kehendak untuk mengelola uang nasabah. Bila BPRS mendapatkan keuntungan, maka nasabah akan mendapatkan bonus dari keuntungan langsung yang dibukukan pada rekening tabungan penabung setiap bulan. Adapun besarnya bonus ditentukan berdasarkan keuntungan yang didapat dan sesuai dengan kebijakan BPRS.

Total tabungan sampai akhir tahun 2016 adalah Rp117 miliar, jumlah tabungan ini selalu meningkat setiap tahunnya. Dana pihak ketiga berupa tabungan dan deposito meningkat secara rata-rata yaitu sebesar $12.77 \%$ dan $13.44 \%$. Total pembiayaan dan aset BPRS Amanah Ummah terus meningkat setiap tahunnya dengan perkembangan sebesar $29.26 \%$ dan $14.99 \%$.

Tabel 2. Perkembangan Tabungan,

Deposito, Pembiayaan, dan Aset BPRS

\begin{tabular}{|l|c|c|c|c|}
\multicolumn{5}{c}{ Amanah Ummah 2014-2016 } \\
\hline $\begin{array}{c}\text { Keterang } \\
\text { an } \\
\text { (Ribuan } \\
\text { Rupiah) }\end{array}$ & 2014 & 2015 & 2016 & $\begin{array}{c}\text { Perke } \\
\text { mbang } \\
\text {-an } \\
(\%)\end{array}$ \\
\hline Tabungan & 90088 & 102528 & 117534 & 12.77 \\
& 208 & 002 & 944 & \\
\hline Deposito & 44423 & 51827 & 59872 & 13.44 \\
& 815 & 699 & 296 & \\
\hline Pembiaya & 1434 & 5723 & 8090 & 29.26 \\
an & 174 & 326 & 409 & \\
\hline Aset & 153 & 178386 & 209847 & 14.99 \\
& 699 & 559 & 343 & \\
& 208 & & & \\
\hline
\end{tabular}

Sumber: ojk.go.id (2017)

\section{Gambaran Umum KSPPS Tadbiirul Ummah}

KSPPS Tadbiirul Ummah pertama kali didirikan sebagai Lembaga Pemberdayaan Masyarakat di daerah Desa Babakan, Kecamatan Dramaga, Kabupaten Bogor atas inisiatif beberapa mahasiswa IPB. Seiring dengan berjalannya waktu KSPPS Tadbiirul Ummah dengan dibantu oleh Yayasan
PERAMU (Pemberdayaan Mustadhafiin) dibentuk menjadi Baitul Maal wattamwil (yang sekarang disebut dengan Koperasi Simpan Pinjam dan Pembiayaan Syariah atau KSPPS) pada tanggal 20 Desember 1995. Pada tanggal 8 Agustus 1998 KSPPS Tadbiirul Ummah mendapatkan izin operasi sebagai koperasi dengan jumlah anggota awal 20 orang dan modal disetor sesebsar Rp9 juta. Sampai akhir tahun 2015 jumlah modal yang berhasil dibukukan sebesar Rp306 juta dengan total aset sebesar Rp13,5 Milyar dan total anggota (pembiayaan dan penyimpan dana aktif) kurang lebih sebanyak 3.500 orang.

KSPPS Tadbiirul Ummah menggunakan sistem jemput bola, yaitu dimana petugas jemput bola mendatangi nasabah untuk bertransaksi. Kantor KSPPS Tadbiirul Ummah berada di Jl Raya Dramaga Kabupaten Bogor. Kantor ini didirikan di tempat yang strategis karena disekitarnya terdapat banyak UMKM. Selain itu kantor KSPPS Tadbiirul Ummah mudah dijangkau oleh kendaraan umum dan letaknya di tepi jalan sehingga mudah dilihat.

Total tabungan sampai akhir tahun 2016 adalah Rp7 miliar, jumlah tabungan ini pernah mengalami penurunan pada tahun 2015. Dana pihak ketiga berupa tabungan meningkat sebesar $27.86 \%$. Sedangkan dana pihak ketiga berupa deposito menurun sebesar $2.05 \%$. Total pembiayaan dan aset KSPPS Tadbiirul Ummah terus meningkat setiap tahunnya dengan perkembangan masing-masing sebesar $3.88 \%$ dan $13.82 \%$. 
Tabel 3. Perkembangan Tabungan, Deposito, Pembiayaan, dan Aset KSPPS

Tadbiirul Ummah 2014-2016

\begin{tabular}{|l|c|c|c|c|}
\hline $\begin{array}{c}\text { Keteranga } \\
n \\
\text { (Ribuan } \\
\text { Rupiah) }\end{array}$ & 2014 & 2015 & 2016 & $\begin{array}{c}\text { Perkemba } \\
\text { ngan (\%) }\end{array}$ \\
\hline Tabungan & 5294 & 5135 & 7119 & 27.86 \\
& 966 & 624 & 785 & \\
\hline Deposito & 4891 & 6198 & 6065 & -2.05 \\
& 451 & 583 & 455 & \\
\hline Pembiayaa & 6140 & 6717 & 6989 & 3.88 \\
n & 628 & 425 & 020 & \\
\hline Aset & 12628 & 13779 & 15989 & 13.82 \\
& 107 & 425 & 745 & \\
\hline
\end{tabular}

Sumber: KSPPS Tadbiirul Ummah (2017) KSPPS Tadbiirul Ummah menawarkan berbagai produk, salah satunya adalah TAMAM (Tabungan Mitra Muamalah). Produk simpanan TAMAM adalah salah satu produk pemupukan dana dari anggota atau calon anggota KSPPS Tadbiirul Ummah dengan akad wadiah yad dhomanah, artinya akad titipan dimana penerima titipan (wadii') dapat memanfaatkan barang titipan (wadiah) dengan seizin pemiliknya (muwaddi') dan menjamin mengembalikan barang titipan secara utuh setiap saat, ketika pemilik memintanya. Dalam hal ini yang dititipkan adalah uang maka tanggung jawab wadii' hanya mencakup nilai uang yang dititipkan, tidak pada sifat uang yang dititipkan. Sebagai pemanfaat barang titipan, maka penerima titipan, yaitu KSPPS Tadbiirul Ummah diperbolehkan membagi keuntungan atas pemanfaatan tersebut sebagai bonus/hadiah kepada pemilik uang yang besarnya tidak ditentukan di awal.

\section{Persyaratan Menabung}

Tabel 4. Persyaratan Menabung di Bank Syariah Mandiri, BPRS Amanah Ummah, dan KSPPS Tadbiirul Ummah

\begin{tabular}{|l|l|l|l|}
\hline Keterangan & \multicolumn{1}{|c|}{ BSM } & \multicolumn{1}{|c|}{ BPRS } & $\begin{array}{l}\text { KSPP } \\
\text { S }\end{array}$ \\
\hline Setoran awal & $\begin{array}{l}\text { Rp80 } \\
000\end{array}$ & $\begin{array}{l}\text { Rp15 } \\
000\end{array}$ & $\begin{array}{l}\text { Rp15 } \\
000\end{array}$ \\
\hline $\begin{array}{l}\text { Setoran } \\
\text { minimum } \\
\text { berikutnya }\end{array}$ & $\begin{array}{l}\text { Rp10 } \\
000\end{array}$ & $\begin{array}{l}\text { Rp10 } \\
000\end{array}$ & $\begin{array}{l}\text { Rp10 } \\
000\end{array}$ \\
\hline
\end{tabular}

\begin{tabular}{|l|l|l|l|}
\hline $\begin{array}{l}\text { Syarat } \\
\text { membuka } \\
\text { rekening }\end{array}$ & $\begin{array}{l}\text { KTP/SIM } \\
\text { /Paspor } \\
\text { dan } \\
\text { NPWP }\end{array}$ & $\begin{array}{l}\text { Fotokopi } \\
\text { KTP/SI }\end{array}$ & $\begin{array}{l}\text { Foto } \\
\text { kopi } \\
\text { KTP/ } \\
\text { SIM }\end{array}$ \\
\hline
\end{tabular}

Sumber: data diolah penulis.

\section{Karakteristik Responden}

Responden dalam penelitian ini terdiri dari nasabah pada tiga lembaga keuangan syariah, yaitu Bank Syariah Mandiri, BPRS Amanah Ummah, dan KSPPS Tadbiirul Ummah. Responden terdiri dari 30 nasabah menabung Bank Syariah Mandiri, 30 nasabah menabung BPRS Amanah Ummah, dan 30 nasabah menabung pada KSPPS Tadbiirul Ummah.

Karakteristik responden berdasarkan usia, lama pendidikan, dan jumlah tanggungan dapat dilihat pada Tabel 5.

Tabel 5. Statistik Deskriptif Karakteristik Responden

\begin{tabular}{|l|r|r|r|r|}
\hline \multicolumn{1}{|c|}{ Variabel } & $\begin{array}{c}\text { Rata- } \\
\text { rata }\end{array}$ & $\begin{array}{c}\text { Maksi } \\
\text { mum }\end{array}$ & $\begin{array}{c}\text { Mini } \\
\text { mum }\end{array}$ & $\begin{array}{r}\text { Standar } \\
\text { Deviasi }\end{array}$ \\
\hline $\begin{array}{l}\text { Bank } \\
\text { Syariah } \\
\text { Mandiri }\end{array}$ & & & & \\
\hline Usia & 37.3 & 56 & 21 & 11.43 \\
\hline $\begin{array}{l}\text { Lama } \\
\text { Pendidikan }\end{array}$ & 15.36 & 21 & 12 & 3.19 \\
\hline $\begin{array}{l}\text { Jumlah } \\
\text { Tanggungan }\end{array}$ & 2.27 & 15 & 0 & 3.06 \\
\hline $\begin{array}{l}\text { BPRS } \\
\text { Amanah } \\
\text { Ummah }\end{array}$ & & & & \\
\hline Usia & 34.9 & 55 & 18 & 10.69 \\
\hline $\begin{array}{l}\text { Lama } \\
\text { Pendidikan }\end{array}$ & 13.8 & 18 & 9 & 2.75 \\
\hline $\begin{array}{l}\text { Jumlah } \\
\text { Tanggungan }\end{array}$ & 1.5 & 4 & 0 & 14 \\
\hline $\begin{array}{l}\text { KSPPS } \\
\text { Tadbiirul } \\
\text { Ummah }\end{array}$ & & & & \\
\hline Usia & 32.6 & 56 & 18 & 9.21 \\
\hline $\begin{array}{l}\text { Lama } \\
\text { Pendidikan }\end{array}$ & 10.7 & 16 & 6 & 2.87 \\
\hline $\begin{array}{l}\text { Jumlah } \\
\text { Tanggungan }\end{array}$ & 2.34 & 9 & 0 & 2.35 \\
\hline $\begin{array}{l}\text { Sumber: Data primer (diolah) } \\
\text { Kumbarat }\end{array}$ & & & & \\
\hline
\end{tabular}

Karakteristik pada segi usia memiliki tingkat keragaman yang cukup besar yang dapat dilihat pada nilai standar deviasi masing-masing responden LKS. Tabel 5 menunjukkan bahwa rata-rata usia nasabah 
menabung pada Bank Syariah lebih tinggi dibandingkan rata-rata usia pada BPRS dan KSPPS. Rata-rata usia responden nasabah Bank Syariah Mandiri adalah 37 tahun dengan standar deviasi sebesar 11.43 , dengan usia maksimum 56 tahun dan usia minimum 21 tahun. Rata-rata usia responden BPRS Amanah Ummah adalah 35 tahun dengan standar deviasi 10.69, dengan usia maksimum 55 tahun dan usia minimum 18 tahun. Rata-rata usia responden KSPPS Tadbiirul Ummah adalah 33 tahun dengan standar deviasi 9.21, dengan usia maksimum 56 tahun dan usia minimum 18 tahun.

Rata-rata lama pendidikan responden Bank Syariah Mandiri adalah 15.36 setara dengan empat tahun untuk tingkat pendidikan S1, dengan lama pendidikan tertinggi yaitu 21 tahun setara dengan S3 dan lama pendidikan terendah yaitu 12 tahun setara dengan SMA. Rata-rata lama pendidikan responden BPRS Amanah Ummah adalah 13.8 tahun setara dengan tiga tahun pendidikan D3, dengan pendidikan tertingga yaitu 18 tahun atau setara dengan S2 dan terendah yaitu 9 tahun atau setara dengan SMP. Rata-rata lama pendidikan responden KSPPS Tadbiirul Ummah adalah 10.7 setara dengan tiga tahun pendidikan SMA, dengan pendidikan tertinggi yaitu 18 tahun atau setara dengan S2 dan terendah yaitu 6 tahun atau setara dengan SD.

Rata-rata jumlah tanggungan responden Bank Syariah Mandiri adalah 2 orang dengan standar deviasi sebesar 3.06. Jumlah tanggungan paling banyak berjumlah 15 orang dan jumlah tanggungan paling sedikit sejumlah 0 orang. Rata-rata jumlah tanggungan responden BPRS Amanah Ummah adalah 1.5 dengan standar deviasi sebesar 1.14. Jumlah tanggungan paling banyak sejumlah 15 orang dan jumlah tanggungan paling sedikit adalah tanpa tanggungan. Rata-rata jumlah tanggungan responden KSPPS Tadbiirul Ummah adalah 2 orang dengan standar deviasi sebesar 2.35. Jumlah tanggungan paling banyak sejumlah 9 orang dan jumlah tanggungan paling sedikit adalah tanpa tanggungan.

\section{Rata-rata pendapatan dan pengeluaran}

Hasil penelitian berdasarkan ratarata pendapatan dan pengeluaran responden per bulan dapat dilihat pada tabel 6.

Tabel 6. Rata-rata Pendapatan dan

Pengeluaran Responden per Bulan

\begin{tabular}{|c|c|c|c|c|c|c|}
\hline \multirow[t]{2}{*}{ Nominal } & \multicolumn{2}{|c|}{ BSM } & \multicolumn{2}{|c|}{ BPRS } & \multicolumn{2}{|c|}{ KSPPS } \\
\hline & $\begin{array}{c}\text { Kuan } \\
\text { titas }\end{array}$ & $\%$ & $\begin{array}{c}\text { Kuan } \\
\text { titas }\end{array}$ & $\%$ & $\begin{array}{l}\text { Kuan } \\
\text { titas }\end{array}$ & $\%$ \\
\hline \multicolumn{7}{|c|}{ Pendapatan per Bulan } \\
\hline$<$ 1Juta & 1 & 3 & 5 & 17 & 5 & 17 \\
\hline $\begin{array}{l}1-2.9 \\
\text { Juta }\end{array}$ & 10 & 33 & 13 & 44 & 12 & 40 \\
\hline $\begin{array}{l}3-4.9 \\
\text { Juta }\end{array}$ & 13 & 44 & 7 & 22 & 3 & 9 \\
\hline $\begin{array}{l}5-10 \\
\text { Juta }\end{array}$ & 2 & 7 & 5 & 17 & 5 & 17 \\
\hline$>10$ Juta & 4 & 13 & 0 & 0 & 5 & 17 \\
\hline \multicolumn{7}{|c|}{ Pengeluaran per Bulan } \\
\hline$<1$ Juta & 2 & 7 & 4 & 13 & 9 & 30 \\
\hline $\begin{array}{l}1-2.9 \\
\text { Juta }\end{array}$ & 8 & 27 & 12 & 40 & 12 & 40 \\
\hline $\begin{array}{l}3-4.9 \\
\text { Juta }\end{array}$ & 8 & 27 & 9 & 30 & 5 & 17 \\
\hline $\begin{array}{l}5 \text { - } 10 \\
\text { Juta }\end{array}$ & 7 & 2 & 5 & 17 & 3 & 10 \\
\hline$>10$ Juta & 5 & 17 & 0 & 0 & 1 & 3 \\
\hline
\end{tabular}

Sumber: Data primer (diolah)

Hasil penelitian menunjukkan bahwa rata-rata pendapatan responden Bank Syariah tertinggi berada pada interval Rp 3.000.000 - Rp. 4.900.000, yaitu sebesar $44 \%$. Sedangkan rata-rata pendapatan responden Bank Syariah paling sedikit berada di bawah Rp. 1.000.000, yaitu sebesar 3\%. Rata-rata pendapatan responden BPRS tertinggi berada pada interval Rp. 1.000.000 - Rp. 2.900.000, yaitu sebesar 44\%. Sedangkan rata-rata pendapatan responden BPRS paling sedikit berada 
diatas Rp. 10.000.000, yaitu sebesar 0\%. Rata-rata pendapatan pada KSPPS tertinggi terdapat pada interval Rp. 1.000.000 - Rp. 2.900.000, yaitu sebesar $40 \%$. Sedangkat rata-rata pendapatan responden KSPPS paling sedikit terdapat pada interval Rp. 3.000.000 Rp. 4.900.000, yaitu sebesar 9\%.

Hasil penelitian menunjukkan bahwa rata-rata pengeluaran responden Bank Syariah paling tertinggi pada interval Rp1 000000 - Rp2 900000 dan Rp. 3.000.000 - Rp. 4.900.000, yaitu sebesar 27\%, sedangkan rata-rata pengeluaran responden Bank Syariah paling sedikit berada di bawah Rp. 1.000.000, yaitu sebesar 0\%. Rata-rata pengeluaran responden BPRS tertinggi berada pada interval Rp. 1.000.000 - Rp. 2.900.000, yaitu sebesar 40\%. Sedangkan rata-rata pengeluaran responden BPRS paling sedikit berada di atas Rp. 10.000.000, yaitu sebesar 0\%. Rata-rata pengeluaran pada KSPPS tertinggi terdapat pada interval Rp. 1.000.000 - Rp. 2.900.000, yaitu sebesar $40 \%$. Sedangkan rata-rata pengeluaran responden KSPPS paling sedikit terdapat di atas Rp. 10.000.000, yaitu sebesar 3\%.

\section{Jenis Pekerjaan Responden}

Hasil penelitian berdasarkan jenis pekerjaan responden menunjukkan bahwa BPRS memiliki nasabah dengan jenis pekerjaan yang lebih beragam dibandingkan dengan nasabah Bank Syariah dan KSPPS, diantaranya PNS, karyawan swasta, karyawan BUMN, mahasiswa/pelajar, wirausaha, dan lainnya. Jenis pekerjaan yang memiliki persentase terbesar pada Bank Syariah Mandiri dan BPRS Amanah Ummah adalah PNS masing-masing sebesar 43\% dan 37\%. Berbeda dengan KSPPS Tadbiirul Ummah yang hanya memiliki dua jenis pekerjaan saja, yaitu wirausaha dan karyawan swasta dengan persentase masing-masing sebesar $63 \%$ dan $37 \%$. Jenis pekerjaan ini membuat sangat pentingnya sistem jemput bola, karena seorang wirausaha relatif tidak sempat meninggalkan pekerjaan untuk mengunjungi lokasi KSPPS dengan langsung. Sedangkan jenis pekerjaan terkecil pada Bank Syariah Mandiri yaitu nasabah dengan pekerjaan sebagai karyawan BUMN sebesar $0 \%$. Responden BPRS Amanah Ummah yang memiliki persentase jenis pekerjaan terkecil adalah karyawan BUMN sebesar $3 \%$.

\section{Intensitas nasabah menabung}

Hasil penelitian berdasarkan intensitas responden menabung dapat dilihat pada tabel 7 .

Tabel 7. Intensitas dan Nominal Nasabah Menabung

\begin{tabular}{|c|c|c|c|c|c|c|}
\hline \multirow{2}{*}{$\begin{array}{c}\text { Intensitas } \\
\text { dan } \\
\text { Nominal }\end{array}$} & \multicolumn{2}{|c|}{ BSM } & \multicolumn{2}{|c|}{ BPRS } & \multicolumn{2}{|c|}{ KSPPS } \\
\hline & $\begin{array}{l}\text { Kuan } \\
\text { titas }\end{array}$ & $\%$ & $\begin{array}{l}\text { Kua } \\
\text { ntit } \\
\text { as } \\
\end{array}$ & $\%$ & $\begin{array}{l}\text { Kuan } \\
\text { titas }\end{array}$ & $\%$ \\
\hline \multicolumn{7}{|l|}{ Per Hari } \\
\hline$<50000$ & 0 & 0 & 1 & 3 & 6 & 21 \\
\hline $\begin{array}{l}50000- \\
100000\end{array}$ & 0 & 0 & 2 & 7 & 12 & 40 \\
\hline$>100000$ & 0 & 0 & 2 & 7 & 3 & 10 \\
\hline \multicolumn{7}{|l|}{ Per Minggu } \\
\hline$<100000$ & 0 & 0 & 1 & 3 & 4 & 13 \\
\hline $\begin{array}{l}100000- \\
300000\end{array}$ & 0 & 0 & 3 & 10 & 1 & 3 \\
\hline$>300000$ & 0 & 0 & 2 & 7 & 0 & 0 \\
\hline \multicolumn{7}{|l|}{ Per Bulan } \\
\hline$<300000$ & 1 & 3 & 1 & 3 & 0 & 0 \\
\hline $\begin{array}{l}300000- \\
700000\end{array}$ & 11 & 27 & 2 & 7 & 3 & 10 \\
\hline$>700000$ & 8 & 27 & 9 & 29 & 0 & 0 \\
\hline \multicolumn{7}{|c|}{$\begin{array}{l}\text { Lainnya (Intesitas Menabung di Atas Per } \\
\text { Bulan) }\end{array}$} \\
\hline$<700000$ & 4 & 13 & 2 & 7 & 1 & 3 \\
\hline $\begin{array}{l}700000- \\
1500000\end{array}$ & 3 & 10 & 2 & 7 & 0 & 0 \\
\hline$>1500000$ & 3 & 10 & 3 & $\begin{array}{l}1 \\
0\end{array}$ & 0 & 0 \\
\hline
\end{tabular}

Sumber: Data primer (diolah)

Hasil penelitian menunjukkan perbedaan intensitas menabung pada reponden nasabah Bank Syariah, BPRS, dan KSPPS. Pada Bank Syariah nasabah paling banyak menabung dengan intensitas sebulan sekali dengan 
nominal rata-rata Rp300 000 - Rp700 000 sebesar $37 \%$. Pada BPRS nasabah paling banyak menabung dengan intensitas sebulan sekali dengan nominal rata-rata di atas $\mathrm{Rp700} 000$ sebesear 29\%. Hal ini dikarenakan nasabah memilih untuk mengumpulkan uangnya terlebih dahulu kemudian disetorkan pada waktu tertentu kepada teller. Pada KSPPS nasabah paling banyak menabung dengan intensitas per hari dengan nominal rata-rata Rp50 000 - Rp100 000 sebesar 40\%. Hal ini dikarenakan adanya petugas jemput bola yang aktif mendatangi nasabah setiap hari untuk menarik uang untuk ditabung.

\section{Faktor-faktor yang Memengaruhi Keputusan Nasabah untuk Menabung di Bank Syariah, BPRS, dan KSPPS}

Faktor-faktor yang memengaruhi keputusan nasabah untuk menabung di Bank Syariah, BPRS dan KSPPS dapat dilihat menggunakan analisis faktor. Tujuan dari analisis faktor adalah menyederhanakan dari bentuk hubungan antara beberapa variabel yang diteliti menjadi faktor-faktor yang lebih kecil tetapi tetap mencerminkan variabel awalnya.

Tabel 8 Total Variance Explained Bank Syariah Mandiri

\begin{tabular}{|c|c|c|c|}
\hline $\begin{array}{c}\text { Comp } \\
\text { o-nent }\end{array}$ & Total & $\begin{array}{c}\% \text { of } \\
\text { Variance }\end{array}$ & $\begin{array}{c}\text { Cumulativ } \\
\mathrm{e} \%\end{array}$ \\
\hline \multicolumn{3}{|c|}{ Initial Eiginvalues } \\
\hline 1 & 2.868 & 47.806 & 47.806 \\
\hline 2 & 1.069 & 17.810 & 65.616 \\
\hline 3 & 0.736 & 12.274 & 77.890 \\
\hline 4 & 0.715 & 11.910 & 89.800 \\
\hline 5 & 0.329 & 5.478 & 95.278 \\
\hline 6 & 0.283 & 4.722 & 100.000 \\
\hline Extraction Sums of Squared Loadings \\
\hline 1 & 2.868 & 47.806 & 47.806 \\
\hline 2 & 1.069 & 17.810 & 65.616 \\
\hline \multicolumn{5}{|c|}{ Rotation Sums of Squared Loadings } \\
\hline 1 & 2.298 & 38.299 & 38.299 \\
\hline 2 & 1.639 & 27.317 & 65.616 \\
\hline
\end{tabular}

Sumber: Data primer (diolah)

Pada Bank Syariah Mandiri (Tabel 8) terdapat 2 faktor atau component yang memiliki initial eigenvalues diatas
1, masing-masing bernilai 2.868 dan 1.069. Faktor-faktor yang terbentuk ini memiliki nilai total percentage of variance sebesar $65.616 \%$ yang berarti $65.616 \%$ dari seluruh variabel dapat dijelaskan oleh dua faktor yang terbentuk. Faktor pertama merupakan faktor yang paling besar memberikan keragaman, yaitu sebesar $47.806 \%$.

Tabel 9 Total Variance Explained BPRS Amanah Ummah

\begin{tabular}{|c|c|c|c|}
\hline $\begin{array}{c}\text { Comp } \\
\text { o- } \\
\text { nent }\end{array}$ & Total & $\begin{array}{c}\% \text { of } \\
\text { Varianc } \\
\mathrm{e}\end{array}$ & $\begin{array}{c}\text { Cumulativ } \\
\mathrm{e} \%\end{array}$ \\
\hline \multicolumn{3}{|c|}{ Initial Eiginvalues } \\
\hline 1 & 2.896 & 48.262 & 48.262 \\
\hline 2 & 1.246 & 20.766 & 69.028 \\
\hline 3 & 0.716 & 11.939 & 80.967 \\
\hline 4 & 0.573 & 9.549 & 90.516 \\
\hline 5 & 0.329 & 5.491 & 96.007 \\
\hline 6 & 0.240 & 3.993 & 100.000 \\
\hline \multicolumn{5}{|c|}{ Extraction Sums of Squared Loadings } \\
\hline 1 & 2.896 & 48.262 & 48.262 \\
\hline 2 & 1.246 & 20.766 & 69.028 \\
\hline Rotation Sums of Squared Loadings \\
\hline 1 & 2.286 & 38.106 & 38.106 \\
\hline 2 & 1.855 & 30.922 & 69.028 \\
\hline
\end{tabular}

Sumber: Data primer (diolah)

Pada BPRS Amanah Ummah (Tabel 9) terdapat 2 faktor yang memiliki initial eigenvalues diatas 1, masingmasing bernilai 2.959 dan 1.092 . Faktorfaktor yang terbentuk ini memiliki nilai total percent of variance sebesar $67.510 \%$ yang berarti $67.510 \%$ dari seluruh variabel dapat dijelaskan oleh dua faktor yang terbentuk. Faktor pertama merupakan faktor yang paling besar memberikan keragaman, yaitu sebesar $49.317 \%$.

Tabel 10 Total Variance Explained KSPPS Tadbiirul Ummah

\begin{tabular}{|c|c|c|c|}
\hline $\begin{array}{c}\text { Comp } \\
\text { o- } \\
\text { nent }\end{array}$ & Total & $\begin{array}{c}\% \text { of } \\
\text { Varianc } \\
\mathrm{e}\end{array}$ & $\begin{array}{c}\text { Cumulativ } \\
\mathrm{e} \%\end{array}$ \\
\hline \multicolumn{3}{|c|}{ Initial Eiginvalues } \\
\hline 1 & 2.959 & 49.317 & 49.317 \\
\hline 2 & 1.092 & 18.193 & 67.510 \\
\hline 3 & 0.701 & 11.680 & 79.189 \\
\hline 4 & 0.537 & 8.954 & 88.143 \\
\hline 5 & 0.458 & 7.640 & 95.783 \\
\hline
\end{tabular}




\begin{tabular}{|c|c|c|c|}
\hline 6 & 0.253 & 4.217 & 100.000 \\
\hline \multicolumn{4}{|c|}{ Extraction Sums of Squared Loadings } \\
\hline 1 & 2.959 & 49.317 & 49.317 \\
\hline 2 & 1.092 & 18.193 & 67.510 \\
\hline \multicolumn{4}{|c|}{ Rotation Sums of Squared Loadings } \\
\hline 1 & 2.717 & 45.288 & 45.288 \\
\hline 2 & 1.333 & 22.222 & 67.510 \\
\hline
\end{tabular}

Sumber: Data primer (diolah)

Pada KSPPS Tadbiirul Ummah (Tabel 10) juga terdapat 2 faktor yang memiliki initial eigenvalues diatas 1 , masing-masing bernilai 2.959 dan 1.092. Faktor-faktor yang terbentuk ini memiliki nilai total percentage of variance sebesar $67.51 \%$ yang berarti $67.51 \%$ dari seluruh variabel dapat dijelaskan oleh dua faktor yang terbentuk. Faktor pertama merupakan faktor yang paling besar memberikan keragaman, yaitu sebesar $49.317 \%$.

Pada Tabel 11 disajikan nilai extraction yang terbentuk. Nilai tersebut menunjukkan besarnya persentase varian suatu variabel yang dapat dijelaskan dalam faktor yang terbentuk. Nilai variabel promosi pada Bank Syariah Mandiri sebesar 85.4\%. Hal ini menunjukkan bahwa sekitar 85.4\% varians dari variabel 1 dapat dijelaskan oleh faktor yang akan terbentuk. Demikian seterusnya untuk variabel lainnya, dengan ketentuan bahwa semakin besar nilai communalities maka semakin kuat hubungan dengan faktor yang nantinya akan terbentuk.

Tabel 11. Nilai communalities setiap variabel

\begin{tabular}{|l|c|c|c|}
\hline \multirow{1}{*}{ Variabel } & \multicolumn{3}{|c|}{ Extraction } \\
\cline { 2 - 4 } & $\begin{array}{c}\text { Bank } \\
\text { Syaria } \\
\mathrm{h} \\
\text { Mandi } \\
\text { ri }\end{array}$ & $\begin{array}{c}\text { BPRS } \\
\text { Amana } \\
\mathrm{h} \\
\text { Ummah }\end{array}$ & $\begin{array}{c}\text { KSPPS } \\
\text { Tadbiir } \\
\text { ul } \\
\text { Ummah }\end{array}$ \\
\hline Promosi & 0.854 & 0.458 & 0.627 \\
\hline Kredibilitas & 0.721 & 0.804 & 0.712 \\
\hline Pelayanan & 0.716 & 0.702 & 0.645 \\
\hline $\begin{array}{l}\text { Prinsip } \\
\text { syariah }\end{array}$ & 0.658 & 0.832 & 0.691 \\
\hline Lingkungan & 0.550 & 0.705 & 0.522 \\
\hline Lokasi & 0.437 & 0.640 & 0.855 \\
\hline
\end{tabular}

Sumber: Data primer (diolah)
Selanjutnya pengelompokkan variabel dengan metode varimax. Nilai loading factor yaitu angka yang menunjukkan besarnya korelasi tiap variabel pada kedua faktor yang terbentuk. Pada Tabel 12 dapat dilihat pengelompokkan variabel ke dalam 2 faktor hasil reduksi berdasarkan nilai loading factor tertinggi yang menampilkan nilai loading factor di atas 0.5 .

Hasil dari pengelompokkan variabel dapat dilihat pada Tabel 12 . Tabel 12 menunjukkan faktor pertama yang terbentuk pada Bank Syariah Mandiri terdiri dari pelayanan, kesesuaian dengan prinsip syariah, kredibilitas lembaga, dan lokasi lembaga. Faktor kedua yang terbentuk terdiri dari promosi dan lingkungan tempat tinggal nasabah. Pada BPRS Amanah Ummah faktor pertama yang terbentuk terdiri dari kesesuaian dengan prinsip syariah, pelayanan, dan kredibilitas lembaga. Faktor kedua yang terbentuk terdiri dari lingkungan tempat tinggal nasabah, lokasi lemabaga, dan promosi. Pada KSPPS Tadbiirul Ummah faktor pertama yang terbentuk terdiri dari kredibilitas lembaga, pelayanan, kesesuaian dengan prinsip syariah, lingkungan tempat tinggal nasabah, dan promosi. Faktor kedua yang terbentuk adalah lokasi lembaga.

Tabel 12 menunjukkan pada Bank Syariah Mandiri faktor pertama yang terbentuk dinamakan sebagai faktor pelayanan yang terdiri dari variabel pelayanan, kredibilitas lembaga, kesesuaian dengan prinsip syariah, dan lokasi lembaga. Hal ini disebabkan karena pelayanan berupa keramahan staf, kemudahan dalam bertransaksi, dan kenyamanan tempat bertransaksi yang disediakan Bank Syariah Mandiri sangat baik. Faktor kedua yang terbentuk dinamakan faktor promosi yang terdiri dari variabel promosi dan 
pengaruh lingkungan nasabah. Pada Bank Syariah Mandiri faktor promosi sangat penting karena masyarakat mengetahui keberadaan Bank Syariah Mandiri melalui pengetahuan masingmasing, seperti melalui internet.

Pada BPRS Amanah Ummah faktor pertama yang terbentuk dinamakan faktor kesesuaian dengan prinsip syariah dan pelayanan yang terdiri dari variabel pelayanan, kredibilitas lembaga, dan kesesuaian dengan prinsip syariah. Hal ini disebabkan kepercayaan nasabah terhadap prinsip syariah yang diterapkan oleh BPRS Amanah Ummah. Faktor kedua yang terbentuk dinamakan faktor promosi yang terdiri dari variabel promosi, lokasi lembaga, dan lingkungan tempat tinggal nasabah. Faktor promosi sangat menentukan keputusan nasabah karena nasabah mayoritas mengetahui BPRS Amanah Ummah melalui lingkungan tempat tinggal, lokasi BPRS yang dekat dengan pasar dan terminal, dan melalui mulut ke mulut. Hal ini mempermudah tersebarnya informasi mengenai BPRS Amanah Ummah.

Pada KSPPS Tadbiirul Ummah faktor pertama yang terbentuk adalah faktor kredibilitas lembaga yang terdiri dari variabel promosi, pelayanan, kredibilitas lembaga, kesesuain dengan prinsip syariah, dan lingkungan tempat tinggal. Faktor kredibilitas lembaga mencerminkan kepercayaan nasabah yang menganggap uangnya aman dapat diambil kapan saja saat nasabah sedang membtuhkan uangnya. Sistem jemput bola juga memudahkan transaksi nasabah yang bisa meningkatkan kepercayaan nasabah terhadap lembaga. Faktor kedua yang terbentuk adalah faktor lokasi lembaga. Lokasi lembaga yang dekat dengan tempat tinggal dan tempat kerja nasabah membuat nasabah memutuskan untuk menggunakan jasa KSPPS Tadbiirul Ummah.
Pada KSPPS Tadbiirul Ummah faktor pertama yang terbentuk adalah faktor kredibilitas lembaga yang terdiri dari variabel promosi, pelayanan, kredibilitas lembaga, kesesuain dengan prinsip syariah, dan lingkungan tempat tinggal. Faktor kredibilitas lembaga mencerminkan kepercayaan nasabah yang menganggap uangnya aman dapat diambil kapan saja saat nasabah sedang membtuhkan uangnya. Sistem jemput bola juga memudahkan transaksi nasabah yang bisa meningkatkan kepercayaan nasabah terhadap lembaga. Faktor kedua yang terbentuk adalah faktor lokasi lembaga. Lokasi lembaga yang dekat dengan tempat tinggal dan tempat kerja nasabah membuat nasabah memutuskan untuk menggunakan jasa KSPPS Tadbiirul Umma.

Tabel 12. Rangkuman Hasil analisis faktor

\begin{tabular}{|c|c|c|}
\hline $\begin{array}{c}\text { Lembaga } \\
\text { Keuangan } \\
\text { Syariah }\end{array}$ & Faktor & $\begin{array}{l}\text { Loading } \\
\text { Factor }\end{array}$ \\
\hline \multirow{8}{*}{$\begin{array}{l}\text { Bank Syariah } \\
\text { Mandiri }\end{array}$} & Faktor 1 & \\
\hline & Pelayanan & 0.846 \\
\hline & $\begin{array}{l}\text { Kesesuaian dengan } \\
\text { prinsip syariah }\end{array}$ & 0.756 \\
\hline & Kredibilitas lembaga & 0.696 \\
\hline & Lokasi lembaga & 0.656 \\
\hline & Faktor 2 & \\
\hline & Promosi & 0.924 \\
\hline & $\begin{array}{l}\text { Lingkungan tempat } \\
\text { tinggal nasabah }\end{array}$ & 0.673 \\
\hline \multirow{8}{*}{$\begin{array}{l}\text { BPRS } \\
\text { Amanah } \\
\text { Ummah }\end{array}$} & Faktor 1 & \\
\hline & $\begin{array}{l}\text { Kesesuaian dengan } \\
\text { prinsip syariah }\end{array}$ & 0.911 \\
\hline & Pelayanan & 0.808 \\
\hline & Kredibilitas lembaga & 0.800 \\
\hline & Faktor 2 & \\
\hline & $\begin{array}{l}\text { Lingkungan tempat } \\
\text { tinggal nasabah }\end{array}$ & 0.840 \\
\hline & Lokasi lembaga & 0.776 \\
\hline & Promosi & 0.576 \\
\hline \multirow{8}{*}{$\begin{array}{l}\text { KSPPS } \\
\text { Tadbiirul } \\
\text { Ummah }\end{array}$} & Faktor 1 & \\
\hline & Kredibilitas lembaga & 0.834 \\
\hline & Pelayanan & 0.795 \\
\hline & $\begin{array}{l}\text { Kesesuaian dengan } \\
\text { prinsip syariah }\end{array}$ & 0.757 \\
\hline & $\begin{array}{l}\text { Lingkungan tempat } \\
\text { tinggal }\end{array}$ & 0.706 \\
\hline & Promosi & 0.563 \\
\hline & Faktor 2 & \\
\hline & Lokasi lembaga & 0.924 \\
\hline
\end{tabular}

Sumber: Data primer (diolah) 
Apabila dilihat dari hasil keseluruhan, variabel yang konsisten berada pada faktor satu adalah pelayanan, kesesuaian dengan prinsip syariah, dan kredibilitas lembaga. Dapat disimpulkan bahwa faktor pertama yang paling memengaruhi keputusan nasabah untuk menabung pada ketiga lembaga keuangan syariah tersebut adalah faktor pelayanan yang pada ketiga lembaga memiliki nilai loading factor yang tinggi. Nasabah akan merasa senang senang dan puas apabila dilayani dengan baik oleh pihak lembaga. Pelayanan yang baik dapat membawa nasabah untuk percaya dan bersikap loyal untuk terus menggunakan jasa lembaga keuangan syariah.

Sesuai dengan penelitian Yarsi (2012) yang menyatakan bahwa kualitas pelayanan mencakup keramahan karyawan, kejujuran, kesponana, kepedulian, ketulusan, serta kecepatan dalam melayani nasabah merupakan faktor penting bagi nasabah. Menurut penelitian Abhimantra et al (2013) variabel pelayanan memiliki pengaruh positif terhadap keputusan nasabah untuk menabung di Bank Syariah. Dengan berlandaskan syariat Islam dalam menjalankan aktivitas perbankan dan dengan melengkapinya dengan pelayanan fitur yang memuaskan, membuat reputasi Bank Syariah menjadi baik. Hasil penelitian ini juga sesuai dengan penelitian Daulay (2010) bahwa pelayanan merupakan variabel paling dominan yang memengaruhi keputusan menabung nasabah Bank Syariah.

Variabel yang rata-rata berada pada faktor kedua adalah promosi, lingkungan tempat tinggal nasabah, dan lokasi lembaga. Dapat disimpulkan bahwa faktor yang terbentuk pada faktor kedua adalah faktor promosi, baik promosi langsung yang dilakukan oleh lembaga maupun promosi melalui mulut ke mulut yang dilakukan oleh nasabah. Menurut penelitian Rokhman dan Zamroni (2016) variabel promosi dengan keputusan memilih Bank Syariah memiliki hubungan yang signifikan dan searah atau berbanding lurus. Artinya semakin besar nilai promosi, maka semakin tinggi keputusan nasabah memilih Bank Syariah.

Penelitian ini menunjukkan perbedaan variabel lokasi lembaga pada Bank Syariah Mandiri dengan kedua lembaga lainnya. Pada Bank Syariah Mandiri lokasi lembaga terdapat pada faktor pertama, sedangkan pada kedua lembaga lainnya terdapat pada faktor kedua. Hal ini disebabkan Bank Syariah Mandiri memiliki banyak cabang dan ATM, sehingga untuk bertransaksi nasabah tidak hanya berpatokan pada satu tempat saja. Hal ini juga membuat variabel lokasi bergabung dengan variabel pelayanan, kesesuaian dengan prinsip syariah, dan kredibilitas terhadap lembaga dan menjadi faktor pertama, yaitu faktor pelayanan.

Penelitian ini menunjukkan perbedaan pada KSPPS Tadbiirul Ummah dan kedua lembaga lainnya. Pada KSPPS Tadbiirul Ummah variabel promosi dan lingkungan tempat tinggal nasabah terletak pada faktor satu, sedangkan pada BSM dan BPRS Amanah Ummah terletak pada faktor dua. Hal ini dikarenakan KSPPS menggunakan sistem jemput bola sehingga promosi dan lingkungan tempat tinggal nasabah masuk ke dalam faktor satu dan bergabung dengan variabel kesesuaian dengan prinsip syariah, pelayanan, kredibilitas lembaga, dan lingkungan tempat tinggal nasabah. Lingkungan tempat tinggal nasabah merupakan hal yang sangat berpengaruh karena nasabah bisa saling memengaruhi dan bisa disebut sebagai ajang promosi bagi KSPPS. KSPPS menggunakan sistem jemput bola dimana karyawan dari KSPPS yang mendatangai nasabah untuk 
bertransaksi mengenai tabungan, sehingga petugas KSPPS bukan hanya bertemu dengan nasabahnya saja, tetapi juga dapat menarik nasabah baru yang berada di lingkungan sekitarnya. Responden KSPPS mayoritas memiliki pekerjaan sebagai wirausaha, sehingga mereka memilih untuk menjalankan usahanya yang akan menghasilkan uang dibandingkan mengurus keuangan di lembaga keuangan syariah. Pada BSM dan BPRS Amanah Ummah mayoritas pekerjaan responden adalah PNS, sehingga masih mempunyai banyak waktu untuk mencari info dan mendatangi lembaga keuangan syariah secara langsung. Hal ini yang membuat promosi dan lingkungan tempat tinggal nasabah berada pada faktor satu dan bergabung dengan variabel lainnya.

Pada KSPPS hanya variabel lokasi dengan nilai loading factor 0.924 yang berada pada faktor dua, hal ini disebabkan oleh KSPPS Tadbiirul Ummah menggunakan sistem jemput bola sehingga penting bagi nasabah untuk mengetahui dimana lokasi lembaga untuk membuat rasa percaya dan rasa aman kepada nasabah yang jarang atau tidak pernah mendatangi KSPPS Tadbiirul Ummah.

Faktor dominan yang terbentuk untuk masing-masing lembaga, dapat dilihat dari variabel yang memiliki nilai loading factor tertinggi pada faktor pertama. Pada Bank Syariah Mandiri faktor dominan yang terbentuk adalah pelayanan dengan nilai loading factor sebesar 0.846. Pada BPRS Amanah Ummah adalah faktor kesesuaian dengan prinsip syariah dengan nilai loading factor sebesar 0.911, sedangkan pada KSPPS Tadbiirul Ummah adalah kredibilitas lembaga dengan nilai loading factor sebesar 0.834 .

\section{KESIMPULAN DAN IMPLIKASI}

Berdasarkan karakteristik responden maka mayoritas responden yang menabung pada Bank Syariah dan BPRS adalah PNS, sedangkan pada KSPPS adalah wirausaha dengan skala kecil dan mikro. Intensitas menabung pada responden Bank Syariah dan BPRS adalah perbulan, sedangkan pada KSPPS adalah perhari. Faktor-faktor yang memengaruhi keputusan nasabah untuk menabung pada Bank Syariah adalah faktor pelayanan dan promosi. Faktorfaktor yang sama juga ditemukan pada BPRS ditambah dengan syariah compliance (kepatuhan terhadap prinsip syariah). Faktor-faktor yang memengaruhi keputusan nasabah untuk menabung pada KSPPS adalah kredibilitas terhadap lembaga dan lokasi LKS. Hal ini karena tidak dijaminnya tabungan di KSPPS oleh LPS, sehingga kredibilitas menjadi sangat penting.

Berdasarkan hasil penelitian maka disarankan bagi lembaga keuangan syriah baik bank maupun non bank diupayakan untuk meningkatkan kepercayaan nasabah perlu adanya pelayanan yang baik dan promosi yang menarik. Selain itu bank juga perlu meningkatkan kepatuhan terhadap prinsip syariah karena ini merupakan tuntutan dari nasabah. Perlu dipertimbangkan untuk memasukkan tabungan pada KSPPS sebagai bagian dari perlindungan LPS.

\section{DAFTAR PUSTAKA}

Abdillah FM, Nasution M, Yuningsih A. 2015. Pengaruh Faktor Pendapatan, Pengetahuan zakat, dan Kredibilitas Lembaga Pengelola Zakat Terhadap Kepercayaan Masyarakat pada Lemabaga Pengelola Zakat 
(Kecamatan Medan Satria Kota Bekasi). Jakarta: Redaksi Account.

Abhimantra A, Agustianingsih A, Maulina AR. 2013. Analisis Faktorfaktor yang Memengaruhi Nasabah (Mahasiswa) dalam Memilih Menabung pada Bank Syariah. Depok: Proceeding PESAT.

Afendi FM, Firdaus M, Harmini. 2013. Aplikasi Metode Kuantitatif untuk Manajemen dan Bisnis. Bogor: IPB Press

Alamsyah IE. 2015. Aset BMT Indonesia Capai Rp4.7 Triliun. [internet]. [Diunduh 2017 Januari 24]. Tersedia pada: http//republika.co.id

Aminullah. 2011. Peran Lembaga Penjamin Simpanan (LPS) dalam Melindungi Dana Nasabah Akibat Bank Gagal. Mataram: PKPSM IKIP Mataram.

Arifin, Rifai. 2010. Islamic Banking. Jakarta: Bumi Akasara.

Ascarya. 2007. Akad dan Produk Bank Syariah. Jakarta: RajaGrafindo Persada.

Barata AA. 2003. Dasar-dasar Pelayanan Prima. Jakarta: Elex Media Komputindo.

[BPS] Badan Pusat Statistik. 2016. Kabupaten Bogor dalam Angka. [internet]. [diunduh 2017 April 4]. Tersedia pada: http//bogorkab.bps.go.id

[BI] Bank Indonesia; Departemen Pengembangan UMKM. 2016. Kajian Potensi Keuangan Unbaked People pada Sektor Perikanan. [internet]. [diunduh 2017 April 24]. Tersedia pada: http//bi.go.id

[BI] Bank Indonesia; Humas Bank Indonesia. 2011. Gerai Info. [internet]. [diunduh 2017 April 24]; 17(2): 1 Tersedia pada: http//bi.go.id

Daulay R. 2010. Analisis Pelayanan dan Bagi Hasil terhadap Keputusan Menabung Nasabah pada Bank
Syariah di Kota Medan. Medan: Jurnal Manajemen dan Bisnis.

Fatwa Dewan Syariah Nasional. 2000. Fatwa Dewan Syariah Nasional No. 7 Tahun 2000 tentang Mudharabah. Jakarta: Dewan Syariah Nasional Majelis Ulama Indonesia.

Fatwa Dewan Syariah Nasional. 2000. Fatwa Dewan Syariah Nasional No. 2 Tahun 2000 tentang Tabungan Syariah. Jakarta: Dewan Syariah Nasional Majelis Ulama Indonesia.

Hakim AA. 2011. Fiqih Perbankan Syariah. Bandung: Refika Aditama Handayani J, Hanik SU. 2014. Keputusan Nasabah dalam Memiliki Perbankan Syariah (Studi Kasus pada Nasabah Bank Syariah Mandiri).Semarang: JABPI.

Hasibuan. 2008. Dasar-dasar Perbankan. Jakarta: Bumi Aksara

Hurriyati R. 2010. Bauran Pemasaran dan Loyalitas Konsumen. Bandung: Alfabeta.

Ibrahim dan Rusdianto. 2016. Pengaruh Produk Bank Syariah terhadap Minat Menabung dengan Persepsi Masyarakat sebagai Variabel Moderating di Pati. Kudus: Equilibrium.

Ismail AG, Wibowo KA, Widiyanto. 2016. BMT Praktik dan Kasus. Depok: Rajagrafindo Persada.

Kamarni N. 2012. Faktor-faktor yang Memengaruhi Minat Masyarakat dalam Berhubungan dengan Bank Syariah di Kota Padang. Padang: Jurnal Manajemen dan Kewirausahaan.

Musnaini. 2010. Perilaku Nasabah Non Muslim dalam Bauran Pemasaran terhadap Keputusan Memilih Produk Bank Syariah di Kota Jambi. Jambi: Universitas Jambi.

[OJK] Otoritas Jasa Keuangan. 2013. Laporan Publikasi Bulanan Neraca Bank Syariah Mandiri 2013. 
[intenet]. [diunduh 2017 April 4].

Tersedia pada: http;//ojk.go.id/cfs

[OJK] Otoritas Jasa Keuangan. 2013.

Laporan Publikasi Bulanan Neraca BPRS Amanah Ummah 2013. [intenet]. [diunduh 2017 April 4]. Tersedia pada: http;//ojk.go.id/cfs

[OJK] Otoritas Jasa Keuangan. 2014. Laporan Publikasi Bulanan Neraca Bank Syariah Mandiri 2014. [intenet]. [diunduh 2017 April 4]. Tersedia pada: http;//ojk.go.id/cfs

[OJK] Otoritas Jasa Keuangan. 2014. Laporan Publikasi Bulanan Neraca BPRS Amanah Ummah 2014. [intenet]. [diunduh 2017 April 4]. Tersedia pada: http;//ojk.go.id/cfs

[OJK] Otoritas Jasa Keuangan. 2015. Laporan Publikasi Bulanan Neraca Bank Syariah Mandiri 2015. [intenet]. [diunduh 2017 April 4]. Tersedia pada: http;//ojk.go.id/cfs

[OJK] Otoritas Jasa Keuangan. 2015. Laporan Publikasi Bulanan Neraca BPRS Amanah Ummah 2015. [intenet]. [diunduh 2017 April 4]. Tersedia pada: http;//ojk.go.id/cfs

[OJK] Otoritas Jasa Keuangan. 2016. Laporan Publikasi Bulanan Neraca Bank Syariah Mandiri 2016. [intenet]. [diunduh 2017 April 4]. Tersedia pada: http;//ojk.go.id/cfs

[OJK] Otoritas Jasa Keuangan. 2016. Laporan Publikasi Bulanan Neraca BPRS Amanah Ummah 2016. [intenet]. [diunduh 2017 April 4]. Tersedia pada: http;//ojk.go.id/cfs

[OJK] Otoritas Jasa Keuangan. 2014. Statistik Perbankan Syariah Desember 2014. [internet]. [diunduh 2017 Mei 28]. Tersedia pada: http://ojk.go.id

[OJK] Otoritas Jasa Keuangan. 2017. Statistik Perbankan Syariah Januari 2017. [internet]. [diunduh 2017 Maret 24]. Tersedia pada: http://ojk.go.id

Pratama MA dan Sagara Y. 2016. Penguatan Ekonomi Kerakyatan
Melalui Baitul Maal Tanwil (BMT) sebagai Balai Usaha Mandiri Rakyat Terpadu (BUMRT). Jakarta: Sosio Didaktika.

Republik Indonesia. 1990. Surat Keputusan Menteri Keuangan tentang lembaga keuangan. Jakarta: SK Menteri Keuangan.

Republik Indonesia. 1998. Undangundang No. 10 Tahun 1998 tentang Bank Umum. Jakarta: Sekretariat Kabinet RI

Republik Indonesia. 2008. Undangundang No. 21 Tahun 2008 tentang Bank Syariah. Jakarta: Sekretariat Kabinet RI

Republik Indonesia. 2015. Peraturan Kementrian Koperasi dan Usaha Kecil dan Menengah tentang Koperasi Usaha Simpan Pinjam dan Pembiayaan Syariah. Jakarta: Kementrian Koperasi dan UKM.

Ridwan M. 2011. Manajemen Baituk Maal wa Tamwil (BMT). Yogyakarta (ID): UII Press.

Rokhman W. 2016. Pengaruh Biaya, Angsuran, dan Kualitas Pelayanan terhadapa Kepuasan Nasabah Pembiayaan BMT di Kabupaten Kudus. Kudus : Iqtishadia

Rokhman W, dan Zamroni. 2016. Pengaruh Marketing Mix dan Syariah Compliance terhadap Keputusan Nasabah Memilih Bank Umum Syariah di Kudus. Kudus: Equilibrium.

Setia. 2010. Perilaku Konsumen. Jakarta: Kencana.

Soemitra A. 2010. Bank dan Lembaga Keuangan Syariah. Jakarta: Kencana.

Sugiyono. 2010. Memahami Penelitian Kualitatif. Bandung: Alfabeta.

Sutrisno. 2013. Membangun Model Lembaga Keuangan Islam. Yogyakarta: Ekbisi.

Yarsi. 2012. Analisis Faktor Penentu Menjadi Nasabah Bank Syariah: (Perbandingan Segmen BPR 
Syariah dan Bank Umum/Unit Usaha Syariah di Sumatera Barat).
Padang: Jurnal Kajian Manajemen Bisnis. 